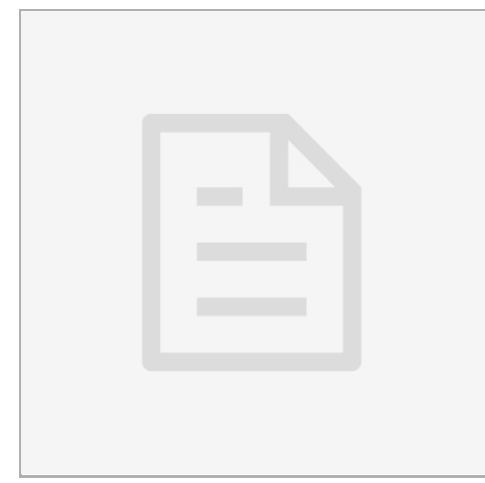

SEP 22, 2019

\section{open $\boldsymbol{\bigodot a c c e s s}$}

\section{DOI:}

dx.doi.org/10.17504/protocol s.io. 7 hrhj56

\section{Protocol Citation: Alba} Balletbó 2019. DNA Purification from an Agarose Gel (Protocol for NucleoSpin ${ }^{\circledR}$ PCR clean-up Gel Extraction Kit). protocols.io https://dx.doi.org/10.17504/p rotocols.io. $7 \mathrm{hrhj56}$

License: This is an open access protocol distributed under the terms of the Creative Commons Attribution License, which permits unrestricted use, distribution, and reproduction in any medium, provided the original author and source are credited

\section{Protocol status: In} development We are still developing and optimizing this protocol

Created: Sep 19, 2019

Last Modified: Sep 22, 2019

PROTOCOL integer ID: 27921

\section{(3) DNA Purification from an Agarose Gel (Protocol for NucleoSpin ${ }^{\circledR}$ PCR clean-up Gel Extraction Kit)}

\author{
Alba Balletbó ${ }^{1}$ \\ ${ }^{1}$ Wageningen University \\ iGEM Wageningen 2019
}

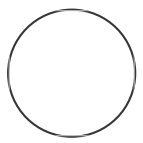

Alba Balletbó

\section{ABSTRACT}

Gel purification allows you to isolate and purify DNA fragments based on size. The procedure starts with standard agarose gel electrophoresis, which separates DNA by their length in base pairs. Following electrophoresis, you can cut DNA bands out of the agarose gel and purify the DNA samples.

\section{GUIDELINES}

Gel purification is most efficient with lower \% agarose gels, so you will want to stay in the $0.7-0.8 \%$ range if possible.

You will want nice crisp bands. This can be achieved by using a wider gel comb and running the gel at a lower voltage.

You will want to have enough space around each band to cut without having DNA in other lanes contaminating your sample. To accomplish this, it is best to skip lanes between samples and between the ladder and nearest sample.

To minimize the risk of DNA damage, it is best to limit the UV exposure of the DNA. Therefore, it is a bad idea to use a gel imager to take a picture of the gel before cutting out the bands and you will want to use long-wavelength UV for as short a time as possible to get the bands cut out.

\section{MATERIALS}

\section{MATERIALS}

$\%$ GeneJET Gel Extraction and DNA Cleanup Micro Kit Thermo Fisher Catalog \#K0832

\title{
Gel Excision
}


1 Once you have run your gel, move it to an open UV box (be sure to wear proper UV protection especially for your eyes!), remove it from any gel tray as plastic will block much of the UV and with a clean, sterile razor blade, slice the desired DNA fragment from the gel.

'Note':To protect the UV box, it is a good idea to place the gel on a glass plate if available. Unlike the plastic tray, this will not significantly reduce the UV, but will protect the UV box from being cut by the razor blade.

'Note': Try to get as little excess gel around the band as possible. To do so, it is often important to take the excised band, lay it down on the UV box and trim the top, bottom and sides with the razor blade. This is especially important during the DNA purification step, as many kits cannot handle more than a certain total volume of gel per reaction.

2 Place the gel in a labeled microfuge tube.

3 Using a scale, weigh the tube with the gel fragment after zeroing the scale with an empty tube. Alternatively, you can just subtract the weight of the empty tube from the weight of the tube with the gel fragment. The weight of the gel is directly proportional to its liquid volume and this is used to determine how much of each buffer to add during the DNA isolation step.

4 Finally, you will want to isolate the DNA from the gel. This is most commonly done with a commercial gel purification kit. Always follow the manufacturer's instructions.

\section{DNA Purification}

$5 \quad$ Add $200 \mu \mathrm{L}$ Binding Buffer (NTI) per $100 \mathrm{mg}$ gel.

6 Incubate the mixture at $50^{\circ} \mathrm{C}$ for $5-10$ minutes or until the gel has completely melted.

7 Place a NucleoSpin ${ }^{\circledR}$ PCR clean-up Gel column in a provided $2 \mathrm{~mL}$ collection tube. 
8 Apply $700 \mu \mathrm{l}$ of the DNA/agarose solution to the NucleoSpin® PCR clean-up Gel column, and centrifuge at $11,000 \times \mathrm{g}$ for $30 \mathrm{~s}$ at room temperature.

9 Discard liquid and place the NucleoSpin ${ }^{\circledR}$ PCR clean-up Gel column back into the same collection tube. For volumes greater than $700 \mu \mathrm{L}$, load the column and centrifuge successively, $700 \mu \mathrm{L}$ at a time. Each NucleoSpin ${ }^{\circledR}$ PCR clean-up Gel column has a total capacity of $25 \mu \mathrm{g}$ DNA. If the expected yield is larger, divide the sample into the appropriate number of columns.

10 Add $700 \mu \mathrm{L}$ of Buffer NT3 into the NucleoSpin ${ }^{\circledR}$ PCR clean-up Gel columnCentrifuge at $11,000 \times \mathrm{g}$ for 30 s at room temperature to wash the column. Discard the flow-through and re-use the collection tube.

11 Repeat step k with another $700 \mu \mathrm{L}$ of Buffer NT3.

12 Discard liquid and centrifuge the empty NucleoSpin ${ }^{\circledR}$ PCR clean-up Gel column for 1 minute at $11,000 \times \mathrm{g}$ to dry the column matrix. Do not skip this step, it is critical for the removal of ethanol from the NucleoSpin ${ }^{8}$ PCR clean-up Gel column.

13 Place a NucleoSpin ${ }^{\circledR}$ PCR clean-up Gel column into a clean $1.5 \mathrm{~mL}$ eppendorf tube. Add 15-30 $\mu \mathrm{L}$ (depending on desired concentration of final product) of Elution Buffer (10 mM Tris- $\mathrm{HCl}, \mathrm{pH} 8.5)$ directly onto the column matrix and incubate at room temperature for 1 minute. Centrifuge for 1 minute at $11,000 \times \mathrm{g}$ to elute DNA. This represents approximately $70 \%$ of bound DNA. An optional second elution will yield any residual DNA, though at a lower concentration. 